\title{
Tahap Pengetahuan, Kemahiran dan Kebolehupayaan Pelatih Pendawaian Elektrik dalam Pembentukan Usahawan Teknikal Di Giatmara Negeri Johor
}

\author{
Mohd Hasril Amiruddin*, Siti Norain Jafaar, Noorazman Abd Samad
}

Fakulti Pendidikan Teknikal dan Vokasional, Universiti Tun Hussein Onn Malaysia, 86400 Batu Pahat, Johor, Malaysia

*Corresponding author: hasril@uthm.edu.my

\begin{abstract}
Technical Entrepreneur involves individuals who have a combination of knowledge, skills and capabilities in technical and entrepreneurship to engage in business. This study aims to identify the knowledge, skills and capabilities possessed by the trainee electrical wiring in GIATMARA Johor state in the formation of technical entrepreneurs. The respondents consisted of 124 students from seven branches GIATMARA Johor which have of course electrical wiring. This study is a descriptive study and data collection methods are conducted using questionnaires instrument set. Data were collected and analyzed using Statistical Package for Social Sciences (SPSS) version 20.0 with regard to the mean and standard deviation. The results showed that the level of knowledge the coach is moderately high with a mean score of 3.86, the level of skills of trainees is moderately high with a mean score of 3.93 and also medium-level coach high reliability with a mean score of 3.96. Overall, the level of knowledge, skills and capabilities to be an entrepreneur coach Technical is moderately high and has a significant relationship. However, the level of knowledge, skills and capabilities can be enhanced to coach a higher level by increasing the entrepreneurial program and initial implementation of the coach electrical wiring in GIATMARA.
\end{abstract}

Keywords: Knowledge; skills; reliability; trainee electrical wiring; technical entrepreneur development

\begin{abstract}
Abstrak
Usahawan teknikal melibatkan individu yang mempunyai kombinasi pengetahuan, kemahiran dan kebolehupayaan dalam bidang teknikal dan bidang keusahawanan untuk melibatkan diri dalam perniagaan. Kajian ini dijalankan bertujuan untuk mengenal pasti tahap pengetahuan, kemahiran dan kebolehupayaan yang dimiliki oleh pelatih Pendawaian Elektrik di GIATMARA negeri Johor dalam pembentukan usahawan teknikal. Responden terdiri daripada 124 orang pelatih dari tujuh cawangan GIATMARA negeri Johor yang mempunyai kursus Pendawaian Elektrik. Kajian ini adalah berbentuk kajian deskriptif dan kaedah pengumpulan data yang dijalankan menggunakan instrumen set borang soal selidik. Data yang dikumpul dan dianalisis menggunakan perisian Statistical Packages for Social Sciences (SPSS) versi 20.0 dengan mengambil kira nilai min dan sisihan piawai. Hasil dapatan kajian mendapati tahap pengetahuan pelatih adalah sederhana tinggi dengan skor min 3.86, tahap kemahiran pelatih adalah sederhana tinggi dengan skor min 3.93 dan tahap kebolehupayaan pelatih juga sederhana tinggi dengan skor min 3.96. Secara keseluruhannya, tahap pengetahuan, kemahiran dan kebolehupayaan pelatih untuk menjadi seorang usahawan teknikal adalah sederhana tinggi dan mempunyai hubungan yang signifikan. Walaubagaimanapun, tahap pengetahuan, kemahiran dan kebolehupayaan pelatih boleh dipertingkatkan ke tahap yang lebih tinggi dengan memperbanyakkan progam keusahawanan dan penerapan awal kepada pelatih Pendawaian Elektrik di GIATMARA.
\end{abstract}

Kata kunci: Pengetahuan; kemahiran; kebolehupayaan; pelatih pendawaian elektrik; pembentukan usahawan teknikal

(C) 2017 Penerbit UTM Press. All rights reserved

\subsection{PENGENALAN}

Kepesatan ekonomi terutamanya dalam bidang keusahawanan kini meransang perkembangan ekonomi negara dan ekonomi dunia. Keusahawanan dikenal pasti sebagai satu bahan penting dalam pembangunan ekonomi sesebuah Negara (Narayan \& Geethakutty, 2003). Ini dapat dilihat apabila semakin banyak usahawan-usahawan berjaya di dalam negara mahupun di negara-negara luar selari dengan permintaan pasaran global (Norasmah, Mohd Hasril \& Mazura, 2011). Keusahawanan dan usahawan memainkan peranan penting dalam membangunkan ekonomi negara yang berhubungkait dengan kepentingan serta keperluan hidup terhadap kelebihan memperbaharui mahupun mempelbagaikan ekonomi dan mencipta peluang pekerjaan baharu (Mohd Hasril et al., 2016).

Berdasarkan kandungan yang termaktub dalam Dasar Ekonomi Baru (DEB) pada tahun 1970 yang menyatakan tentang penyusunan semula ekonomi dan membasmi kemiskinan. Penyusunan semula ekonomi ini lebih kepada untuk menyeimbangkan peratusan penglibatan rakyat negara ini ke dalam bidang perniagaan mengikut bangsa. Maka di sini, jelaslah menunjukkan bahawa bidang keusahawanan itu penting dan mempunyai skop yang luas (Mohd Hasril, Noorazman \& Norasmah, 2015). Menurut Zaidatol (1997); Mohd Hasril, Norasmah \& Ramlee (2009), untuk menjadi seorang usahawan, seseorang itu perlu menyedari ciri-ciri sebagai usahawan yang efektif dan efisien sebelum memasuki bidang perniagaan dan keusahawanan. Seseorang usahawan muncul bukan kerana memiliki ciri-ciri personaliti semula jadi atau dilahirkan, tetapi kerana pelbagai faktor lain dan boleh dilatih (Lope Pihie \& Elias, 1998; Mohd Hasril \& Norasmah, 2010). 
Persepsi untuk menceburi bidang keusahawanan adalah didorong oleh beberapa faktor (Reitan, 1997). Faktor-faktor tersebut adalah pengetahuan yang tinggi, kemahiran serta kebolehupayaan seseorang individu sebelum memasuki dunia keusahawanan (Norasmah \& Mohd Hasril 2010).

Dari segi pemilihan bidang keusahawanan sebagai kerjaya, terdapat laporan yang dikeluarkan oleh Global Entrepreneur Monitor (GEM) pada tahun 2011 menyatakan bahawa Malaysia masih berada dalam kalangan negara-negara yang mempunyai skor rendah iaitu $51.5 \%$ berbanding negara-negara yang mempunyai skor kerjaya keusahawanan tinggi dan sederhana seperti Colombia (89.4\%), Brazil (86.3\%), China (73.1\%) dan Thailand (77.0\%) (Sumber: Global Entrepreneurship Monitor (GEM), 2011 Global Report). Dalam Rancangan Malaysia ke-10 menunjukkan bahawa hanya 28\% daripada jumlah tenaga kerja di negara ini bekerja dalam jenis pekerjaan yang berkemahiran tinggi (Tajuddin, 2011). Ini menunjukkan bahawa tahap kecekapan atau kebolehan tenaga kerja tidak mencapai standard piawaian yang diperlukan oleh sektor perindustrian mahupun bidang keusahawanan yang memerlukan seseorang individu itu bekerja sendiri. Kajian pengesahan graduan yang telah dijalankan oleh pihak Kementerian Pengajian Tinggi (KPT) bagi tahun 2011 menunjukkan bahawa bidang keusahawanan masih belum begitu mendapat tempat untuk menjadi kerjaya pilihan dalam kalangan pelajar IPT tempatan, di mana hanya sekitar 1\% sahaja graduan atau lulusan IPT yang menceburi bidang keusahawanan dalam tempoh enam bulan selepas mereka menamatkan pengajian (Kementerian Pengajian Tinggi, muka surat 16). Masalah-masalah yang sering dihadapi ialah tidak dapat membuat keputusan, kurang maklumat tentang diri dan kerjaya, tiada kepastian tentang kerjaya yang dipilih, kurang minat untuk merancang, dan tidak mampu menyelesaikan masalah (Nasir, 2013).

Kemahiran yang dimiliki oleh para graduan tidak dapat digunakan untuk menyumbang kepada pembangunan negara. Pelbagai pihak mula mempersoalkan kualiti pendidikan di negara ini di mana graduan kurang berpengetahuan dan kemahiran dalam mengendalikan bidang keusahawanan. Walaubagaimanapun, perlaksanaan kurikulum pendidikan di GIATMARA haruslah sentiasa mengikut peredaran zaman bagi memastikan lepasan pelatih yang dilahirkan bukan sahaja mempunyai ilmu pengetahuan malah menguasai kemahiran insaniah dalam menghadapi era globalisasi pada masa kini (Stevenson \& Bell, 2009). Dari aspek pelatih GIATMARA, menurut Yusof (2008), seseorang pekerja perlu mempunyai kemahiran, pengetahuan dan kompeten (kebolehupayaan) dalam melahirkan generasi yang berkemahiran dan seterusnya dapat menyumbang kepada sektor ekonomi negara di masa hadapan.

Oleh itu, kepentingan pengetahuan, kemahiran dan kebolehupayaan dalam membentuk jati diri seseorang usahawan teknikal perlu dititikberatkan kerana mereka merupakan perintis kepda pembangunan ekonomi negara dan dunia (Norasmah, Mohd Hasril \& Haliza 2011). Disebabkan oleh itu, pelatih teknikal di GIATMARA kurang terdedah kepada rancangan keusahawanan. Ini disokong melalui kajian daripada Abd Samad (2008) dan Mohd Hasril et al. (2015), penglibatan para belia dari ILKA seperti Institut Latihan Perindustrian (ILP), Institut Kemahiran Mara (IKM), Institut Kemahiran Belia Negara (IKBN), Kolej Komuniti dan GIATMARA kurang melibatkan diri dalam dunia perniagaan. Pelatih-pelatih GIATMARA tidak mempunyai pengetahuan mengenai keusahawanan yang mendalam, malahan tidak cekap serta kurang kemahiran dan kebolehan dalam mengendalikan urusan keusahawanan. Menurut Gyapong \& Ofori Adjei (2010) pembentukan keupayaan individu mementingkan sokongan dan dorongan terhadap individu untuk memperoleh kemahiran, kemampuan dan pembangunan diri yang lebih sejahtera.

\subsection{TUJUAN KAJIAN DAN OBJEKTIF KAJIAN}

Kajian kes ini dijalankan bertujuan untuk mengkaji tahap pengetahuan, kemahiran dan kebolehupayaan di kalangan pelatih Pendawaian Elektrik terhadap pembentukan usahawan teknikal di GIATMARA negeri Johor sebagai kerjaya selepas tamat latihan. Kajian ini adalah untuk meninjau persepsi pelatih GIATMARA dari segi pengetahuan, kemahiran keusahawanan dan kebolehupayaan dalam membina perniagaan sendiri dan menjadi usahawan teknikal. Dalam kajian ini terdapat empat objektif telah ditetapkan bagi mencapai tujuan kajian ini iaitu:

1. Mengenal pasti persepsi pengetahuan pelatih pendawaian elektrik dalam pembentukan usahawan teknikal.

2. Mengenal pasti kemahiran keusahawanan pelatih pendawaian elektrik dalam pembentukan usahawan teknikal.

3. Mengenal pasti kebolehupayaan pelatih pendawaian elektrik dalam pembentukan usahawan teknikal.

4. Mendapatkan hubungan antara pengetahuan, kemahiran dan kebolehupayaan pelatih Pendawaian Elektrik di GIATMARA Johor dalam pembentukan usahawan teknikal.

\subsection{METODOLOGI}

Reka bentuk kajian yang dijalankan di GIATMARA negeri Johor dilakukan secara statistik deskriptif dengan menggunakan kaedah tinjauan. Menurut Sidek (2002), kajian deskriptif sering digunakan bertujuan untuk memberi penerangan yang sistematik mengenai fakta dan ciri-ciri sesuatu populasi atau bidang yang diminati secara fakta dan tepat. Oleh yang demikian, kajian yang dijalankan adalah berbentuk diskriptif melalui cara soal selidik. Idris (2010) menyatakan kajian tinjauan sangat berguna dalam mengumpul data berhubung fenomena yang tidak dapat diperhatikan secara kasar. Kajian tinjauan ini adalah suatu proses pengumpulan data dan penyelidik meminta sampel atau responden untuk menjawab soalan yang disediakan (Mohd Affandi et al., 2015). Kaedah tinjauan digunakan untuk mengukur pembolehubah-pembolehubah yang berkaitan dengan sesuatu fenomena tanpa menyoal mengapa pembolehubah itu wujud. Kajian ini dibuat bertujuan untuk mengumpulkan maklumat dan data-data mengenai tahap pengetahuan, kemahiran dan kebolehupayaan pelatih Pendawaian Elektrik dalam pembentukan usahawan teknikal di GIATMARA Malaysia negeri Johor. Setiap soalan soal selidik mengandungi arahan soalan-soalan jenis tertutup untuk dijawab oleh responden yang terlibat dalam kajian ini. Seterusnya ujian statistik yang sesuai digunakan dalam menganalisis data yang diperoleh. 


\section{Sampel Kajian}

Populasi ialah kumpulan besar yang memperoleh manfaat daripada hasil kajian saintifik yang dijalankan ke atas sampel. Sabitha Marican (2005) membincangkan bahawa sampel adalah sekumpulan individu, keluarga, kumpulan, organisasi, komuniti, peristiwa atau apa sahaja yang hendak dikaji oleh penyelidik. Sampel yang digunakan di dalam kajian ini adalah seramai 124 orang pelatih Pendawaian Elektrik yang mewakili tujuh buah cawangan GIATMARA Malaysia negeri Johor. Kajian yang dijalankan ini berlokasi di GIATMARA negeri Johor. Terdapat tujuh cawangan di dalam negeri Johor iaitu GIATMARA Batu Pahat, GIATMARA Gelang Patah, GIATMARA Kluang, GIATMARA Kulai, GIATMARA Labis, Komuniti GIATMARA Ledang dan GIATMARA Tebrau. Pemilihan lokasi ini adalah disebabkan bidang Pendawaian Elektrik merupakan bidang yang mempunyai cawangan paling banyak di Johor. Kerajaan Johor telah menubuhkan Entreprenuer Development Centre (EDC) sebagai langkah untuk melahirkan lebih ramai golongan yang dilihat mampu memacu daya saing ekonomi negeri Johor dan juga memupuk serta melahirkan masyarakat enterprais (berbudaya keusahawanan).

\section{Instrumen Kajian}

Menurut Chua (2006), instrumen kajian yang biasanya digunakan dalam penyelidikan sains sosial merupakan soal selidik yang direka untuk mengumpul data yang mempunyai pelbagai kegunaan. Bagi tujuan pengumpulan data untuk kajian ini, penyelidik telah memilih untuk membangunkan soal selidik untuk penyelidikan kuantitatif. Manakala menurut Sekaran (2006), kaedah pengumpulan data melalui kaedah soal selidik merupakan kaedah yang efisyen sebagai salah satu mekanisme yang digunakan untuk pengumpulan data. Kajian ini menggunakan borang soal selidik yang telah diadaptasikan dari beberapa tesis pelajar sarjana Universiti Tun Hussein Onn Malaysia, iaitu Mohd Nur Hafiz Bin Fauzi bertajuk 'Penerapan Budaya, Sikap dan Nilai Terhadap Pembentukan Usahawan Teknikal Dalam Kalangan Pelatih GIATMARA di Kelantan', Suhaili Bt Padil bertajuk 'Aplikasi Kemahiran Insaniah Dalam Kurikulum Program Kejuruteraan Di Politeknik', Mohd Hafeez Al-Amin Bin Abdul Wahab bertajuk 'Penerapan Kemahiran Keusahawanan Dalam Kalangan Pelajar Bidang Kejuruteraan Mekanikal di UTHM', Mohd Shahzuan Bin Ghazalan bertajuk 'Persepsi Peserta Program Pembelajaran Sepanjang Hayat (PSH) Bidang Pastri Terhadap Tahap Kesediaan Dalam Kecenderungan Menceburi Keusahawanan Di Kolej Komuniti Negeri Johor' dan buku panduan elemen keusahawanan dari bahagian pembangunan kurikulum (2010).

Soal selidik ini telah diubahsuai bagi memenuhi keperluan kajian yang dilakukan oleh penyelidik. Soal selidik ini menggunakan Likert berskala 5 bagi membantu penyelidik menjalankan kajian. Penggunaan set soal selidik sebagai instrumen kajian adalah sesuai dengan had masa yang terhad dan responden tidak dipengaruhi oleh tingkah laku penyelidik. Manakala Rensis Linkert (1932) mencadangkan bahawa indeks yang dibina perlu ditambah item-item berkaitan dengan sesuatu konsep yang digunakan di dalam kajian ini. Kajian ini memfokuskan kepada kesahan konstrak dalam membina item-item. Justeru itu, bagi menentukan kesahan instrumen kajian ini, penyelidik meminta bantuan daripada pakar-pakar di UTHM yang mempunyai pengalaman dalam bidang keusahawanan dan pengurus GIATMARA yang pakar dalam aspek pelatih GIATMARA itu sendiri bagi memastikan instrumen itu bersesuaian dengan pelatih GIATMARA sebagai responden dan memeriksa penggunaan ayat yang digunakan adalah betul.

Menurut Mohamad Majid Konting (1990), kebolehpercayaan memberi darjah kekekalan dan ketepatan bagi tujuan instrumen pengukuran. Proses kebolehpercayaan juga turut dilakukan ke atas instrumen dan item supaya tidak berlaku sebarang pertindanan dan terus menjurus kepada pembinaan item serta tidak terkeluar daripada ruang bidang kajian. Bagi menentukan kebolehpercayaan instrumen, analisis Alpha Cronbanch digunakan. Nilai alpha $(\alpha)$ kurang dari 0.6 menunjukkan kebolehpercayaan yang rendah manakala melebihi 0.7 merupakan kebolehpercayaan yang baik (Mohd Majid, 1994). Kaedah ini menggunakan beberapa soalan untuk sesuatu konsep. Sekiranya responden memberikan jawapan yang sama untuk semua soalan tersebut, maka jawapan boleh dipercayai dan jawapan tersebut mempunyai tahap kebolehpercayaan yang tinggi.

Hasil kajian rintis yang dijalankan ke atas 40 orang pelatih Pendawaian Elektrik di dua buah cawangan GIATMARA Melaka iaitu GIATMARA Bukit Katil dan GIATMARA Masjid Tanah dan setelah dianalisis menggunakan perisian Statistical Package for Social Science (SPSS) for Windows versi 20.0 dapat dirumuskan bahawa kebolehpercayaan item soal selidik berada di tahap yang tinggi dengan nilai Alpha Cronbach melebihi 0.7. Jadual 1 menunjukkan nilai Alpha Cronbach yang diperolehi setelah menjalankan kajian rintis terhadap pelatih Pendawaian Elektrik di GIATMARA Melaka. Nilai Alpha Cronbach untuk Bahagian B, C dan D adalah masing-masing 0.922, 0.920 dan 0.941 dengan nilai keseluruhan ialah 0.963 . Oleh itu, setiap bahagian di dalam borang soal selidik berada pada nilai julat 0.90 yang menunjukkan tahap kebolehpercayaan setiap konstruk berada di tahap yang tinggi.

Jadual 1 Nilai Alpha Cronbach dari kajian rintis

\begin{tabular}{ccc}
\hline Bahagian & Jumlah item & Nilai Alpha Cronbach \\
\hline Bahagian B & 19 & 0.922 \\
Bahagian C & 19 & 0.920 \\
Bahagian D & 23 & 0.941 \\
Keseluruhan Bahagian & 61 & 0.963 \\
\hline
\end{tabular}

\section{Analisis data}

Analisis data merupakan perkara yang penting dalam menentukan hasil sesuatu kajian yang dilaksanakan. Menurut Simon (1978), analisis data yang baik adalah apabila analisis daripada data tersebut dapat difahami dengan mudah oleh para pembaca. Di dalam kajian ini, data dianalisis dengan menggunakan analisis deskriptif dan menggunakan kaedah kuantitatif serta diproses menggunakan Statistical Packages for the Sosial Science version 20.0 (SPSS 20.0) untuk mendapatkan nilai min daripada setiap elemen dalam kajian ini. Jadual 2 menunjukkan pembolehubah dan kaedah analisis data yang diperolehi. 
Jadual 2 Pembolehubah dan kaedah analisis data

\begin{tabular}{|c|c|c|}
\hline Bahagian & Pembolehubah & Kaedah Analisis Data \\
\hline Objektif 1 & $\begin{array}{c}\text { Pengetahuan } \\
\text { Bersandar: Pembentukan usahawan teknikal } \\
\text { Tidak bersandar: Persepsi pengetahuan pelatih GIATMARA }\end{array}$ & Deskriptif: skor min \\
\hline Objektif 2 & $\begin{array}{c}\text { Kemahiran } \\
\text { Bersandar: Pembentukan usahawan teknikal } \\
\text { Tidak bersandar: Kemahiran keusahawanan pelatih GIATMARA }\end{array}$ & Deskriptif: skor min \\
\hline Objektif 3 & $\begin{array}{c}\text { Kebolehupayaan } \\
\text { Bersandar: Pembentukan usahawan teknikal } \\
\text { Tidak bersandar: Kebolehupayaan pelatih GIATMARA }\end{array}$ & Deskriptif: skor min \\
\hline Objektif 4 & $\begin{array}{c}\text { Hubungan } \\
\text { Bersandar: Pembentukan usahawan teknikal } \\
\text { Tidak bersandar: Hubungan antara pengetahuan, kemahiran dan } \\
\text { kebolehupayaan pelatih GIATMARA }\end{array}$ & $\begin{array}{c}\text { Inferensi: Kolerasi } \\
\text { Spearman's Rank Order }\end{array}$ \\
\hline
\end{tabular}

\subsection{KEPUTUSAN}

Reka bentuk borang soal selidik kajian terbahagi kepada beberapa bahagian di mana setiap bahagian (kecuali Bahagian A iaitu demografi responden) akan menjawab persoalan kajian. Bahagian demografi mempunyai perkaitan dengan kajian yang dilakukan. Analisis demografi terbahagi kepada empat item utama iaitu lokasi cawangan GIATMARA, jantina, kursus Pendawaian Elektrik yang diambil dan pengalaman di dalam perniagaan. Terdapat tujuh buah cawangan GIATMARA negeri Johor yang dipilih oleh penyelidik untuk menyempurnakan kajian yang dijalankan ini. Pelatih GIATMARA Tebrau mempunyai jumlah pelatih yang paling ramai iaitu seramai 24 orang $(22.6 \%)$ berbanding GIATMARA Kulai, iaitu seramai 7 orang $(6.6 \%)$. Ini adalah disebabkan oleh ketidakhadiran pelatih semasa kedatangan penyelidik. Soal-selidik telah diedarkan kepada 124 orang pelatih GIATMARA bidang Pendawaian Elektrik. Namun, sejumlah 106 set borang soal selidik yang lengkap dan dikembalikan. Daripada 106 orang tersebut, bilangan pelatih lelaki adalah 105 orang $(99.06 \%)$ dan seorang perempuan $(0.94 \%)$. Pelatih lelaki memonopoli kursus ini berbanding pelatih perempuan. Kursus ini lebih kepada kemahiran teknikal yang memerlukan tenaga yang banyak. Oleh itu, pelatih perempuan kurang menceburi bidang ini.

Kursus Pendawaian Elektrikal ini terbahagi kepada empat tahap iaitu PW1, PW2, PW3 dan PW4. Walaubagaimanapun, pada masa kajian ini dijalankan GIATMARA hanya menawarkan tiga tahap iaitu PW1, PW2 dan PW dan pensampelan melibatkan keseluruhan responden daripada ketiga-tiga tahap ini. Kursus Pendawaian Elektrik tahap PW2 mempunyai paling ramai pelatih iaitu seramai 89 orang (84\%). Majoriti pelatih adalah lepasan SPM dan mahu mengaplikasikan kemahiran yang dimiliki di kawasan yang menggunakan Sistem Pendawaian Elektrik 1 Fasa. Kajian ini mengambil kira pengalaman perniagaan yang pernah dijalankan oleh pelatih Pendawaian Elektrik. Pengalaman di dalam perniagaan memberi kesan bagi membentuk jati diri sebagai seorang usahawan. Ironiknya pelatih tidak mempunyai pengalaman di dalam perniagaan dengan mempunyai kekerapan tertinggi (72 orang dengan peratusan $67.9 \%$ ).

\section{Persepsi Pengetahuan Pelatih Pendawaian Elektrik Dalam Pembentukan Usahawan Teknikal}

Bahagian B soal selidik merupakan set item mengenai persepsi pengetahuan pelatih Pendawaian Elektrik untuk menjadi usahawan teknikal. Jadual 3 menunjukkan min keseluruhan dan intepretasi min bagi tahap pengetahuan yang dikaji oleh penyelidik. Dua elemen telah dikeluarkan oleh penyelidik bagi mengukur tahap pengetahuan pelatih iaitu pemikiran ke arah keusahawanan dan kesediaan pengetahuan terhadap keusahawanan. Kedua-dua elemen ini masing-masing menunjukkan nilai min 3.83 dan 3.88 , yang berada di tahap sederhana tinggi. Purata keseluruhan skor min yang diperolehi adalah 3.86 di mana pelatih Pendawaian Elektrik bersetuju dari aspek pengetahuan, pemikiran dan kesediaan pengetahuan keusahawanan perlu ada di dalam diri individu yang ingin menceburi diri dalam bidang keusahawanan dan menjadi usahawan teknikal dengan menubuhkan perniagaan sendiri tanpa mengamalkan budaya makan gaji.

Jadual 3 Min keseluruhan dan interpretasi min bagi elemen pengetahuan

\begin{tabular}{ccc}
\hline Elemen Pengetahuan & Min & Interpretasi Min \\
\hline Pemikiran ke arah keusahawanan & 3.83 & Sederhana Tinggi \\
Kesediaan pengetahuan terhadap keusahawanan & 3.88 & Sederhana Tinggi \\
Purata skor min keseluruhan & 3.86 & Sederhana Tinggi \\
\hline
\end{tabular}

Kemahiran Keusahawanan Pelatih Pendawaian Elektrik Dalam Pembentukan Usahawan Teknikal

Persoalan kajian kedua adalah untuk melihat tahap kemahiran pelatih Pendawaian Elektrik di GIATMARA Johor dalam pembentukan usahawan teknikal. Kemahiran ini melibatkan kemahiran keusahawanan yang dimiliki oleh pelatih Pendawaian Elektrik. Bagi menjawab persoalan kajian yang kedua ini, penyelidik telah menganalisis set soal selidik yang telah diedarkan kepada pelatih Pendawaian Elektrik. Pada bahagian ini, penyelidik menganalisis bahagian $\mathrm{C}$ pada set borang soal selidik di mana bahagian $\mathrm{C}$ mempunyai tiga elemen yang diketengahkan oleh penyelidik dalam menjalankan kajian ini. Elemen-elemen tersebut ialah daya kreativiti dan inovatif, membina jaringan sosial dan menyelesaikan masalah.

Jadual 4 menunjukkan min keseluruhan dan intepretasi min bagi elemen kemahiran keusahawanan yang telah dijalankan oleh penyelidik. Terdapat tiga elemen yang diketengahkan oleh penyelidik dalam usaha pembentukan usahawan teknikal iaitu daya kreativiti dan inovatif, membina jaringan sosial dan menyelesaikan masalah. Purata julat keseluruhan min bagi elemen ini adalah antara 3.76 hingga 
4.12. Elemen membina jaringan sosial mendapat nilai min yang paling tinggi iaitu 4.12 dan berada di tahap tinggi. Ini menunjukkan pelatih amat bersetuju dengan membina jaringan sosial dapat meluaskan rangkaian perniagaan ke serata dunia. Walaubagaimanapun, pelatih juga bersetuju bahawa daya kreativiti dan inovatif penting dalam pembentukan usahawan teknikal di mana perbezaan perniagaan yang maju dan tidak terletak pada kreativiti produk yang dihasilkan. Semakin canggih dan kreatif sesuaatu produk, semakin laris jualan yang dilakukan. Secara kesimpulannya, purata skor min keselurhan bagi elemen kemahiran ini ialah 3.91 dan berada di tahap sederhana tinggi. Ini menunjukkan keperluan kemahiran keusahawanan dalam pembentukan usahawan teknikal.

Jadual 4 Min keseluruhan dan interpretasi min bagi elemen kemahiran keusahawanan

\begin{tabular}{cccc}
\hline Elemen Kemahiran Keusahawanan & Min & Interpretasi Min \\
\hline Daya kreativiti dan inovatif & 3.76 & Sederhana Tinggi \\
Membina jaringan sosial & 4.12 & Tinggi \\
Menyelesaikan masalah & 3.85 & Sederhana Tinggi & 3.91 \\
Purata skor min keseluruhan & Sederhana Tinggi \\
\hline
\end{tabular}

\section{Kebolehupayaan Pelatih Pendawaian Elektrik Dalam Pembentukan Usahawan Teknikal}

Persoalan kajian ketiga adalah untuk melihat tahap kebolehupayaan pelatih Pendawaian Elektrik di GIATMARA Johor dalam pembentukan usahawan teknikal. Bagi menjawab persoalan kajian yang ketiga ini, penyelidik telah menganalisis set soal selidik yang telah diedarkan kepada pelatih Pendawaian Elektrik. Pada bahagian ini, penyelidik menganalisis bahagian D pada set borang soal selidik di mana bahagian D mempunyai empat elemen yang diketengahkan oleh penyelidik dalam menjalankan kajian ini. Elemen-elemen tersebut ialah daya tahan yang kental, fleksibiliti, berkeupayaan memimpin dan kesanggupan belajar dari kesilapan.

Bagi kebolehupayaan, kesanggupan belajar dari kesilapan menunjukkan nilai min paling tinggi iaitu 4.07, manakala daya tahan yang kental menunjukkan nilai min paling rendah iaitu 3.86. Ini adalah disebabkan oleh setiap permasalahan yang berlaku, seorang usahawan perlu mempunyai kebolehupayaan sanggup belajar dari kesilapan supaya masalah yang terjadi tidak berulang. Purata skor min keseluruhan bagi elemen ini ialah 3.97 dan berada di tahap sederhana tinggi (Jadual 5). Ini bermakna kebolehupayaan untuk menjadi usahawan teknikal masih berada di tahap sederhana tinggi dan pelatih belum bersedia sepenuhnya untuk menjadikan bidang keusahawanan sebagai kerjaya.

Jadual 5 Min keseluruhan dan interpretasi min bagi elemen kebolehupayaan

\begin{tabular}{cccc}
\hline Elemen Kebolehupayaan & Min & Interpretasi Min \\
\hline Daya tahan yang kental & 3.86 & Sederhana Tinggi \\
Fleksibiliti & 3.95 & Sederhana Tinggi & Sederhana Tinggi \\
Berkeupayaan memimpin & 3.98 & 4.07 & Tinggi \\
Kesanggupan belajar dari kesilapan & 3.97 & Sederhana Tinggi \\
Purata skor min keseluruhan & & & \\
\hline
\end{tabular}

Kebolehupayaan Pelatih Pendawaian Elektrik Dalam Pembentukan Usahawan Teknikal

Analisis ini bertujuan untuk menjawab persoalan kajian yang keempat iaitu adakah terdapat hubungan antara pengetahuan, kemahiran dan kebolehupayaan pelatih Pendawaian Elektrik di GIATMARA Johor dalam pembentukan usahawan teknikal. Dalam bahagian ini, penyelidik telah membuat pengujian terhadap hipotesis kajian ini. Ujian statistik bagi menguji hipotesis ini adalah menggunakan Kolerasi Spearman's Rank Order kerana hasil ujian normaliti menunjukkan data yang diperolehi tidak normal. Justeru itu, analisis ujian Kolerasi Spearman's Rank Order yang dijalankan ditunjukkan seperti dalam Jadual 6.

Jadual 6 Hubungan antara tahap pengetahuan, kemahiran dan kebolehupayaan pelatih Pendawaian Elektrik dalam pembentukan usahawan teknikal

\begin{tabular}{|c|c|c|c|c|c|}
\hline & & & Pengetahuan & Kemahiran & Kebolehupayaan \\
\hline \multirow[t]{9}{*}{ Spearman's rho } & Pengetahuan & Pekali korelasi & 1.000 & $.598^{* *}$ & $.731^{* *}$ \\
\hline & & Sig. (2-hujung) & . & .000 & .000 \\
\hline & & $N$ & 106 & 106 & 106 \\
\hline & Kemahiran & Pekali korelasi & $.598^{* *}$ & 1.000 & $.661^{* *}$ \\
\hline & & Sig. (2-hujung) & .000 & . & .000 \\
\hline & & $N$ & 106 & 106 & 106 \\
\hline & Kebolehupayaan & Pekali korelasi & $.731^{* *}$ & $.661^{* *}$ & 1.000 \\
\hline & & Sig. (2-hujung) & .000 & .000 & . \\
\hline & & $N$ & 106 & 106 & 106 \\
\hline
\end{tabular}

**Korelasi signifikan pada aras 0.01(2-hujung)

Analisis ujian Kolerasi Spearman's Rank Order digunakan untuk menjawab persoalan kajian keempat menggunakan hipotesis kajian iaitu hasil keputusan menunjukkan bahawa terdapat hubungan antara pengetahuan, kemahiran dan kebolehupayaan pelatih Pendawaian Elektrik di GIATMARA Johor dalam pembentukan usahawan teknikal. Hipotesis kajian adalah seperti berikut: 
Ho: Tidak wujud hubungan antara pengetahuan, kemahiran dan kebolehupayaan pelatih Pendawaian Elektrik di GIATMARA Johor dalam pembentukan usahawan teknikal.

Ha: Terdapat hubungan antara pengetahuan, kemahiran dan kebolehupayaan pelatih Pendawaian Elektrik di GIATMARA Johor dalam pembentukan usahawan teknikal.

Bagi menentukan sama ada terdapat hubungan antara tahap pengetahuan, tahap kemahiran dan tahap kebolehupayaan pelatih Pendawaian Elektrik di GIATMARA Johor dalam pembentukan usahawan teknikal, analisis ujian Kolerasi dan keputusan bergantung kepada aspek-aspek berikut:

Kebarangkalian $\mathrm{p}>.05$, maka Ha ditolak.

Kebarangkalian $\mathrm{p}<.05$, maka Ha diterima.

Kolerasi Spearman's Rank Order melaporkan perkaitan kolerasi pasangan pembolehubah yang diuji, serta memberikan maklumat paras signifikan dan juga jumlah kes. Keputusan ujian Kolerasi Spearman's Rank Order merujuk kepada nilai pada Pearson Correlation. Bagi menjalankan analisis hipotesis, merujuk kepada Jadual 4.18, hubungan pekali kolerasi bagi pasangan pembolehubah pengetahuan dan kemahiran adalah sederhana iaitu di antara 0.41-0.60 di mana nilai Correlation Coefficient $=.598^{*}$ dengan paras signifikan .000 (Sig. (2tailed)). Oleh kerana nilai $\mathrm{p}<.05$, maka hasil kajian menerima hipotesis alternatif (Ha). Keputusan ini membuktikan bahawa pembolehubah pengetahuan dan kemahiran mempunyai satu perkaitan positif 0.598 dan nilai varians bagi kedua-dua pemboleh ubah adalah $35.76 \%((.598 \times$ x .598) x 100). Hubungan linear positif (.598) menggambarkan tahap kemahiran meningkat selaras dengan pengetahuan tetapi di dalam keadaan sederhana pada kadar $35.76 \%$. Walhal, hubungan pekali bagi pasangan pembolehubah pengetahuan dan kebolehupayaan adalah kuat iaitu di antara 0.61-0.80 di mana nilai Correlation Coefficient $=.731^{*}$ dengan paras signifikan .000 (Sig. (2-tailed)). Oleh kerana nilai $\mathrm{p}<.05$, maka hasil kajian menerima hipotesis alternatif (Ha). Keputusan ini membuktikan bahawa pembolehubah pengetahuan dan kebolehupayaan mempunyai satu perkaitan positif 0.731 dan nilai varians bagi kedua-dua pemboleh ubah adalah $53.44 \%((.731 \times$ x .731) x 100). Hubungan linear positif (.731) menggambarkan tahap kebolehupayaan meningkat selaras dengan pengetahuan di dalam keadaan kuat pada kadar $53.44 \%$.

Selain itu, hubungan pekali bagi pasangan pembolehubah kemahiran dan pengetahuan adalah sederhana iaitu di antara 0.41-0.60 di mana nilai Correlation Coefficient $=.598^{*}$ dengan paras signifikan .000 (Sig. (2-tailed)). Oleh kerana nilai $\mathrm{p}<.05$, maka hasil kajian menerima hipotesis alternatif (Ha). Keputusan ini membuktikan bahawa pembolehubah kemahiran dan pengetahuan mempunyai satu perkaitan positif 0.598 dan nilai varians bagi kedua-dua pemboleh ubah adalah $35.76 \%$ ((.598 x .598) x 100). Hubungan linear positif (.598) menggambarkan tahap pengetahuan meningkat selaras dengan kemahiran di dalam keadaan sederhana tetapi di dalam kadar $35.76 \%$. Walaubagaimanapun, hubungan pekali bagi pasangan pembolehubah kemahiran dan kebolehupayaan adalah kuat iaitu di antara 0.61-0.80 di mana nilai Correlation Coefficient $=.661^{*}$ dengan paras signifikan .000 (Sig. (2-tailed)). Oleh kerana nilai $\mathrm{p}<.05$, maka hasil kajian menerima hipotesis alternatif (Ha). Keputusan ini membuktikan bahawa pembolehubah pengetahuan dan kebolehupayaan mempunyai satu perkaitan positif 0.598 dan nilai varians bagi kedua-dua pemboleh ubah adalah $43.69 \%$ ( (.661 x .661) x 100). Hubungan linear positif (.661) menggambarkan tahap kebolehupayaan meningkat selaras dengan kemahiran di dalam keadaan kuat pada kadar $43.69 \%$.

Tambahan lagi, hubungan pekali bagi pasangan pembolehubah kebolehupayaan dan pengetahuan adalah kuat iaitu di antara 0.61-0.80 di mana nilai Correlation Coefficient $=.731^{*}$ dengan paras signifikan .000 (Sig. (2-tailed)). Oleh kerana nilai $\mathrm{p}<.05$, maka hasil kajian menerima hipotesis alternatif (Ha). Keputusan ini membuktikan bahawa pembolehubah kebolehupayaan dan pengetahuan mempunyai satu perkaitan positif 0.598 dan nilai varians bagi kedua-dua pemboleh ubah adalah $53.44 \%$ ((.731 x .731) x 100). Hubungan linear positif (.731) menggambarkan tahap pengetahuan meningkat selaras dengan kebolehupayaan di dalam keadaan kuat pada kadar 53.44\%. Namun, hubungan pekali bagi pasangan pembolehubah kebolehupayaan dan kemahiran adalah juga kuat iaitu di antara 0.61-0.80 di mana nilai Correlation Coefficient $=.661^{*}$ dengan paras signifikan .000 (Sig. (2-tailed)). Oleh kerana nilai $\mathrm{p}<.05$, maka hasil kajian menerima hipotesis alternatif (Ha). Keputusan ini membuktikan bahawa pembolehubah kebolehupayaan dan kemahiran mempunyai satu perkaitan positif 0.598 dan nilai varians bagi kedua-dua pemboleh ubah adalah 43.69\% ((.661 x .661) x 100). Hubungan linear positif (.661) menggambarkan tahap kemahiran meningkat selaras dengan kebolehupayaan di dalam keadaan kuat pada kadar 43.69\%. Secara keseluruhan dari hasil analisis kajian ini, keputusan hipotesis alternatif (Ha) diterima dan hipotesis null (Ho) ditolak. Oleh yang demikian, persoalan keempat dapat dijawab iaitu wujud hubungan antara tahap pengetahuan, tahap kemahiran dan tahap kebolehupayaan bagi pelatih Pendawaian Elektrik di GIATMARA Johor dalam pembentukan usahawan teknikal.

\subsection{DAPATAN DAN PERBINCANGAN}

Bahagian ini terdiri daripada dapatan dan perbincangan kajian berdasarkan objektif dan persoalan kajian yang telah ditetapkan.

\section{Tahap Pengetahuan Pelatih Pendawaian Elektrik Di GIATMARA Johor Dalam Pembentukan Usahawan Teknikal}

Kesediaan pengetahuan terhadap keusahawanan dalam mengenalpasti jenis dan kaedah untuk memulakan perniagaan yang berkesan untuk membantu menghadapi segala cabaran dan membuat perancangan strategi yang sistematik. Perkara ini disokong oleh kajian Yusof (2000) yang menyatakan pengambilan, pencarian dan penggunaan maklumat yang berkesan dapat dilakukan sekiranya usahawan peka dan telah bersedia terlebih dahulu sebelum memulakan perniagaan dengan mengumpul ilmu pengetahuan mengenai perniagaan terlebih dahulu. Kemampuan seseorang peniaga dalam mendirikan perniagaan sendiri berbekalkan kajian, pemerhatian dan persediaan awal dari segi pengetahuan teknikal dan juga pengetahuan keusahawanan mampu membantu seseorang individu itu untuk berjaya. Secara keseluruhannya hasil kajian menunjukkan bahawa responden bersetuju dengan tahap pengetahuan seseorang itu dapat membentuk keperibadian seseorang individu dalam meminati dan menceburkan diri dalam bidang keusahawanan yang berisiko tetapi ianya berbaloi untuk dijalankan bagi menjana sumber kewangan. Kenyataan ini disokong oleh hasil kajian daripada Farid (2007) menyatakan bahawa usahawan adalah individu yang memiliki tenaga dan semangat tinggi, lebih bertoleransi daripada orang lain terhadap risiko dan ketidakpastian. 
Oleh itu, pengetahuan dalam keusahawanan teknikal ini merupakan suatu kerjaya besar dalam mewujudkan peluang pekerjaan kepada belia yang berkemahiran dan berkebolehupayaan dalam bidang teknikal untuk menceburi diri dalam bidang perniagaan. Perkara ini dapat meningkatkan penglibatan belia dalam sektor keusahawanan bagi menjana pemikiran atau idea untuk memulakan perniagaan yang bertujuan untuk mempertingkatkan tahap pengetahuan, kemahiran, keupayaan pengurusan usahawan yang berkualiti dan berupaya mengurus projek-projek perdagangan dalam perindustrian kecil, sederhana dan besar dalam memajukan sumber pendapatan negara supaya dapat bersaing dengan negara luar melalui pelbagai cara di antaranya dengan pembacaan artikel, majalah, akhbar dan buku - buku yang berkaitan dengan keusahawanan. Perkara ini turut disokong oleh hasil kajian Ramachandra (2013) yang menyatakan bahawa pengetahuan adalah ilmu dari pembacaan yang tidak terhad dapat meningkatkan pengetahuan seseorang ke tahap yang tinggi. Idea yang dikeluarkan oleh individu yang berpengetahuan tinggi lebih bernas dan kreatif serta inovatif daripada individu yang tidak mempunyai pengetahuan yang tinggi.

\section{Tahap Kemahiran Pelatih Pendawaian Elektrik Di GIATMARA Johor Dalam Pembentukan Usahawan Teknikal}

Kajian ini menunjukkan bahawa terdapat beberapa ciri-ciri kemahiran mengenai pembentukan usahawan teknikal dalam diri seseorang individu berdasarkan beberapa elemen iaitu daya kreativiti dan inovatif dalam mencipta sesuatu yang baharu dan menyelesaikan masalah dengan logika. Kebolehan ini menjana idea alternatif dan memperkembangkan idea baru serta berkongsi pandangan dengan orang lain terhadap sesuatu peluang, situasi dan masalah. Perkara ini disokong oleh kajian Fauzi (2014) yang menyatakan bahawa untuk menjadi seorang usahawan yang berjaya perlulah mempunyai minda yang kreatif supaya dapat mencipta sesuatu yang baharu. Seterusnya elemen membina jaringan sosial, di mana usahawan perlu mempunyai kemahiran mengenai jaringan sosial untuk meluaskan perniagaan yang dijalankan. Dengan adanya bantuan jaringan sosial perniagaan ianya dapat memastikan perniagaan yang dimiliki dikenali ramai dan mendapat sambutan dari perniaga-perniaga lain untuk menjalinkan usahasama untuk mencapai kejayaan dalam perniagaan (Kementerian Pelajaran Malaysia, 2010).

Selain itu elemen penyelesaian masalah juga penting bagi seseorang peniaga untuk berfikir dan berikhtiar untuk menghasilkan sesuatu perkara yang baru dan berlainan dengan orang lain yang dapat diterima oleh masyarakat sekeliling. Kemahiran berfikir membolehkan manusia menyelesaikan masalah dalam situasi tertentu berdasarkan teori yang berkaitan malahan mahir mengaplikasikan teori dan teknikal ke dalam penghasilan sesuatu produk yang baru. Hasil dapatan kajian Yaakub \& Ahmad (2003) turut mendapati kemahiran menyelesaikan masalah dengan berfikir membolehkan seseorang itu melihat pelbagai perspektif merangkumi pemikiran reflektif, kritis dan kreatif yang digunakan untuk menyelesaikan masalah dalam situasi tertentu. Secara keseluruhannya responden bersetuju bahawa tahap kemahiran keusahawanan dalam pembentukan usahawan teknikal adalah penting bagi seseorang individu itu mula menceburkan diri dalam bidang perniagaan terutamanya dari segi daya kreativiti dan inovatif, membina jaringan sosial dan menyelesaikan masalah. Ini menunjukan bahawa kemahiran teknikal adalah proses perlaksanaan yang membolehkan sesuatu program, simulasi dan projek yang dapat dijalankan dengan baik berdasarkan pengalaman yang pernah dilalui. Selaras dengan kajian Abdul Aziz (2000), kemahiran merupakan pendidikan formal yang telah diperkembangkan melalui latihan yang sesuai dan pengalaman yang diperolehi daripada kerja yang pernah dilakukan ketika belajar ataupun praktikal.

\section{Tahap Kebolehupayaan Pelatih Pendawaian Elektrik Di GIATMARA Johor Dalam Pembentukan Usahawan Teknikal}

Kajian ini mengenengahkan beberapa ciri-ciri kebolehupayaan mengenai pembentukan usahawan teknikal diantaranya ialah daya tahan yang kental adalah merupakan sesuatu perkara yang perlu ada dalam diri setiap usahawan bagi menghadapi pelbagai cabaran dan halangan sebaik sahaja menubuhkan perniagaan. Malahan usahawan perlulah mempunyai daya kekuatan mental, fizikal dan emosi yang tinggi untuk terus bertahan dalam bidang perniagaan (Kementerian Pelajaran Malaysia, 2010). Seterusnya elemen fleksibiliti yang merupakan kebolehan menyesuaikan diri terhadap perubahan persekitaran seperti permintaan pelanggan dan perniagaan seorang usahawan adalah satu ciri usahawan yang berjaya. Pada masa kini persaingan dalam dunia perniagaan adalah hebat di mana setiap perniagaan perlulah berfikiran terbuka dan sentiasa mengeluarkan idea - idea baru bagi meningkatkan dan memasarkan produk yang diperkenalkan untuk jangka masa yang lama. Malahan menurut hasil kajian Yusof (2000) yang menyatakan seseorang yang ingin menceburi bidang keusahawanan perlu memiliki kebolehan-kebolehan yang tertentu di dalam mengendalikan aktiviti keusahawanan untuk bersaing dalam bidang perniagaan.

Selain itu, elemen berkeupayaan memimpin juga perlu ada dalam diri perniagaan supaya dapat mengawal sistem pengoperasian keseluruhan sesuatu perniagaan. Perkara ini adalah penting untuk seseorang usahawan apabila berhadapan dengan pelanggan atau pihakpihak tertentu supaya lebih peka dan sensitif terhadap permasalahan yang berlaku dalam perniagaan. Kenyataan ini disokong dalam kajian Abdul (2008) iaitu seorang usahawan pemimpin yang peka dan sensitif terhadap permasalahan yang berlaku, bersedia menerima kepelbagaian pendapat bersama pekerja mereka bagi memudahkan pengoperasian perniagaan yang dibina. Manakala elemen terakhir adalah kesanggupan belajar dari kesilapan membuatkan seseorang usahawan itu berjaya kerana berani menerima kegagalan sebelum mencapai kejayaan. Kegagalan merupakan satu pengajaran supaya kesilapan yang sama tidak diulangi dan dapat memperbaiki peluang seseorang untuk mencapai kejayaan (Kementerian Pelajaran Malaysia, 2010). Secara keseluruhannya responden bersetuju bahawa tahap kebolehupayaan pelatih Pendawaian Elektrik di GIATMARA Johor dalam pembentukan usahawan teknikal memerlukan seorang pelatih usahawan yang berjaya dan sanggup menerima kegagalan sebagai satu keperluan untuk mencapai kejayaan. Dengan kebolehupayaan sedemikian, seseorang akan dapat memperbaiki peluang untuk mencapai kejayaan (Kementerian Pelajaran Malaysia, 2010).

Hubungan Antara Pengetahuan, Kemahiran Dan Kebolehupayaan Pelatih Pendawaian Elektrik Di GIATMARA Johor Dalam Pembentukan Usahawan Teknikal

Hasil dapatan kajian menunjukkan bahawa tahap pengetahuan, kemahiran dan kebolehupayaan pelatih mempunyai hubungan hubungan yang signifikan di antara satu sama lain. Ini bermakna ketiga-tiga elemen usahawan teknikal ini adalah perlu ada dalam diri seseorang usahawan untuk menjadi perniaga yang berkualiti dan berupaya mengurus projek-projek perdagangan mahupun perindustrian kecil dan sederhana yang berdaya maju, berdaya saing dan berdaya tahan. Dengan itu, bagi menghasilkan individu yang memiliki tenaga dan semangat tinggi, lebih bertoleransi daripada orang lain terhadap risiko dan ketidakpastian, mendambakan autonomi dan kecekalan 
mencapai matlamat di sebalik pelbagai cabaran dan kekurangan sumber perlulah mempunyai elemen pengetahuan, kemahiran dan kebolehupayaan yang tinggi pelatih bagi membentukan usahawan teknikal yang berjaya.

Ini selaras dengan hasil kajian Hussin (2008), mendapati tahap pengetahuan dan penguasaan kemahiran terhadap bidang keusahawanan dalam kalangan responden berada pada tahap yang tinggi. Ini menunjukkan tahap pengetahuan dan penguasaan kemahiran yang dimiliki oleh pelajar terhadap bidang keusahawanan mempengaruhi sikap pelajar untuk menceburi bidang keusahawanan untuk berkongsi idea dan dapat meningkatkan pembangunan minda pelajar dalam membuat keputusan sendiri semasa menjalankan sesuatu perniagaan. Perkara ini turut di sokong oleh kajian Padil (2012) dan Amiruddin et al. (2016) yang menyatakan bahawa tahap kemahiran keusahawanan melibatkan tahap keupayaan seseorang individu untuk meneroka peluang dan membangunkan kesedaran tentang risiko, kreativiti dan inovasi dalam aktiviti berkaitan perniagaan dan pekerjaan.

\subsection{KESIMPULAN}

Daripada kajian yang telah dijalankan beberapa kesimpulan akan dinyatakan daripada dapatan kajian mengenai tahap pengetahuan, kemahiran dan kebolehupayaan pelatih Pendawaian Elektrik dalam pembentukan usahawan teknikal di GIATMARA negeri Johor. Secara keseluruhannya kajian ini mendapati bahawa ketiga-tiga elemen usahawan teknikal ini perlu ada pada setiap individu yang ingin menceburi bidang keusahawanan, mengikut kesemua konstruk tahap pengetahuan berada pada tahap sederhana tinggi kerana kebanyakan respoden bersetuju bahawa pemikiran ke arah keusahawanan penting untuk menjadi seorang usahawan dalam menubuhkan perniagaan sendiri. Manakala bagi konstruk kesediaan pengetahuan terhadap keusahawanan menunjukkan bahawa responden amat bersetuju jika menghasilkan rancangan pemasaran yang baik sebagai kesediaan awal sebelum menceburi bidang keusahawanan. Responden perlu mempunyai pengetahuan untuk mentakrif konsep keusahawanan ke dalam produk yang akan dihasilkan. Selain itu, tahap kemahiran ini melibatkan kemahiran keusahawanan yang dimiliki oleh pelatih Pendawaian Elektrik. Dapatan kajian dapat dirumuskan bahawa tahap kemahiran dari aspek daya kreativiti dan inovatif berada di tahap sederhana tinggi, ianya sesuai diamalkan dalam sesebuah perniagaan yang dibangunkan oleh usahawan untuk mahir dalam menjana idea secara kreatif dan inovatif terhadap sesuatu produk yang dihasilkan.

Manakala, kemahiran membina jaringan sosial juga penting dalam membentuk usahawan teknikal kerana ianya memberi manfaat kepada responden untuk menghasilkan perancangan dan strategi sendiri sekiranya berlaku masalah, dapat bertukar idea, dapat bergabung tenaga dan dapat berkongsi kemahiran yang dimiliki untuk kebaikan bersama. Begitu juga, bagi elemen menyelesaikan masalah dari aspek kemahiran keusahawanan, responden bersetuju untuk mencuba pelbagai kaedah yang berbeza bagi mencari penyelesaian terbaik. Kemahiran menganalisis hubungan antara teori dengan praktikal sesuatu produk perlu bagi meningkatkan kualiti produk yang dihasilkan oleh usahawan sebagai persediaan menghadapi cabaran dan halangan untuk memulakan sesebuah perniagaan. Perkara ini menunjukkan bahawa kemahiran keusahawanan perlu dalam pembentukan usahawan teknikal. Seterusnya bagi tahap kebolehupayaan pelatih Pendawaian Elektrik di GIATMARA Johor dalam pembentukan usahawan teknikal. Ini menunjukkan bahawa sebagai persediaan awal sebelum bergelar usahawan teknikal, pelatih perlu mempunyai daya tahan yang kental dan tidak mudah mengalah untuk mencapai kejayaan hasil titik peluh sendiri. Responden juga bersetuju bahawa untuk membangunkan sesebuah perniagaan, pelatih perlu bertahan dalam menangani masalah yang dihadapi yang memerlukan kekuatan fizikal dan pengawalan emosi yang tinggi. Elemen fleksibiliti bagi tahap kebolehupayaan yang dikaji menunjukkan sederhana tinggi kerana pelatih bersetuju untuk melaksanakan permintaan pelanggan yang pelbagai semasa menjalankan perniagaan dan berkebolehan untuk menunaikan permintaan serta memuaskan hati pelanggan mereka. Bagi melaksanakan aktiviti yang melibatkan kemahiran yang membolehkan mereka menambah ilmu serta kebolehupayaan supaya boleh diaplikasikan di dalam perniagaan mereka nanti.

Bagi menjawab persoalan kajian mengenai hubungan antara pengetahuan, kemahiran dan kebolehupayaan pelatih Pendawaian Elektrik di GIATMARA Johor dalam pembentukan usahawan teknikal, hasil keputusan menunjukkan bahawa terdapat hubungan antara pengetahuan, kemahiran dan kebolehupayaan pelatih kerana setiap elemen saling berkait antara satu sama lain bagi menghasilkan seorang pelatih yang bersedia menceburkan diri dalam bidang keusahawanan. Perhubungan ini akan mempengaruhi sikap dan minda pelajar untuk menceburi bidang keusahawanan. Oleh itu, ianya adalah satu elemen yang penting bagi membentuk semangat keusahawanan dalam diri pelajar dengan mempelajari semua ilmu pengetahuan mengenai usahawan, disamping melatih diri untuk meningkatkan kemahiran diri serta berkeupayaan menguruskan perniagaan sendiri dengan usaha sepenuhnya bagi menghadapi segala rintangan dan cabaran yang bakal dilalui untuk berjaya kelak.

Beberapa cadangan untuk kajian lanjutan yang difikirkan sesuai untuk dijalankan ialah menjalankan kajian terhadap tahap penguasaan pelatih Pendawaian Elektrik di seluruh GIATMARA dan Menjalankan kajian perbandingan tahap kesungguhan pelatih di GIATMARA dengan pelatih Pendawaian Elektrik di ILK untuk melibatkan diri dalam pembentukan usahawan teknikal.

\section{Rujukan}

Abd Samad, N. (2008). Penerapan Nilai, Ilmu dan Budaya Usahawan Di Giatmara-Satu Tinjauan. Tesis Sarjana. Fakulti Pendidikan Universiti Kebangsaan Malaysia, Bangi.

Abdul Wahab, M. H. A. A. (2013). Penerapan Kemahiran Keusahawanan dalam Kalangan Pelajar Bidang Kejuruteraan Mekanikal di UTHM. Tesis Sarjana. Universiti Tun Hussein Onn Malaysia.

Amiruddin, M.H., Ngadiman, N., Abdul Kadir, R. \& Saidy, S. (2016). Soft Skills Of Tvet Trainees From The Malaysian Advanced Technology Training Center (ADTEC). Journal of Technical Education and Training (JTET). 8(1), 14-24.

Chua, Y. P. (2006). Kaedah dan Statistik Penyelidikan Buku 1. Malaysia: McGraw-Hill (Malaysia) Sdn. Bhd. Communication Skills (CS) Among Lecturer on Vocational Teaching and Learning in Vocational College Zone Johor, Malaysia.. International Journal of Vocational Education and Training Research 2015; $1(4), 55-61$.

Farid, M. (2007). Entrepreneurship in Egypt and The US Compared, Journal of Management Development, 26(5), 428-440.

Fauzi, M. N. H. (2014). Penerapan Budaya, Sikap dan Nilai Terhadap Pembentukan Usahawan Teknikal dalam Kalangan Pelatih GIATMARA di Kelantan. Tesis Sarjana. Universiti Tun Hussein Onn Malaysia.

Ghazalan, M. S. (2015). Persepsi Peserta Program Pembelajaran Sepanjang Hayat (PSH) Bidang Pastri Terhadap Tahap Kesediaan Dalam Kecenderungan Menceburi Keusahawanan di Kolej Komuniti Negeri Johor. Tesis Sarjana. Universiti Tun Hussein Onn Malaysia. 
Gyapong, J. O. \& D. Ofori-Adjei. (2010). Capacity Building for Relevant Health Research in Developing Countries. Accra, Ghana: Health Research Unit Ghana Health Service. Dalam free-books-online.net/Capacity-Building-for-Relevant-Health Research in Developing Countries.pdf.

Hussin, H., A. Zakaria, \& M. S. Salleh. (2008). Memperkasakan Mahasiswa Kejuruteraan Menerusi Penerapan Kemahiran Insaniah (Soft Skills) [Versi Elektronik]. International Conference on the Roles of the Humanities and Social Sciencec in Engineering 2008 (ICOHSE08), 583-596.

Idris, N. (2010). Penyelidikan Dalam Pendidikan. Malaysia: McGraw-Hill Sdn. Bhd.

K. Ismail, Ab. (2010). Kementerian Pelajaran Malaysia. Buku Panduan Elemen Keusahawanan. Bahagian Pembangunan Kurikulum, 2-7.

Konting, M. M. (1993). Kaedah Penyelidikan Pendidikan. Kuala Lumpur: Dewan Bahasa dan Pustaka Paul

Konting, M. M. (1998). Kaedah Penyelidikan Pendidikan. Kuala Lumpur: Dewan Bahasa Pustaka.

Likert, R. (1932). A Technique For The Measurement Of Attitudes. Archives of Psychology, 140, 1-55.

Mohd Affandi, H., Amiruddin, M. H., Che Hassan, Y. \& Zainudin, F. L. (2015). Knowledge Of, Attitude And Awareness Towards Research Practice Among Malaysian Premier Polytechnics Academics. Journal of Technical Education and Training (2), 1-7.

Mohd Hasril Amiruddin \& Norasmah Othman. (2010). Meninjau Keperluan Pendidikan Keusahawanan Berdasarkan Kepada Perspektif Belia Orang Asli Di Selatan Malaysia. Seminar 2nd World Congress On Teacher Education For TVET 2010

Mohd Hasril Amiruddin, Faizal Amin Nur Yunus, Mohamad Hisyam Mohd Hashim, Mohd Bekri Rahim, \& Mohd Luqman Abd Rahim. (2015) Application of

Mohd Hasril Amiruddin, Isma Atiqah Ngadiran, Fathin Liyana Zainudin, \& Norhayati Ngadiman. (2016). Tahap kemahiran generik pelajar Malaysia dalam proses pengajaran dan pembelajaran: Kajian kes pelajar Institut Kemahiran Mara, Johor Baharu.. Themed Issue On Technological, Vocational And Educational Empowerment Of Malaysia's Human Resource. GEOGRAFIA OnlineTM Malaysian Journal of Society and Space, 12(3), 111 - 121

Mohd Hasril Amiruddin, Noorazman Abd. Samad \& Norasmah Othman. (2015). An Investigation Effects Of Mastery Learning Strategy On Entrepreneurship Knowledge Acquisition Among Aboriginal Students. Procedia Social and Behavioral Sciences 204(2015), 183-90

Mohd Hasril Amiruddin, Norasmah Othman \& Ramlee Mustapha. (2009). Potensi Masyarakat Orang Asli Dalam Bidang Keusahawanan. Seminar Kebangsaan Pembangunan Keusahawanan 2009. Universiti Kebangsaan Malaysia \& Institut Keusahawanan Negara (INSKEN).

Narayan, S. N. P., S. Geethakutty. (2003). Level of Entrepreneurial Success Among Women Entrepreneurs in Agribusiness. Journal of Tropical Agriculture, 41, 4144.

Norasmah Othman \& Mohd Hasril Amiruddin. (2010). The Readiness Of The Orang Asli Youths In Venturing Into Entrepreneurship. 9th WSEAS International Conference on Education And Educational Technology (EDU '10).

Norasmah Othman, Mohd Hasril Amiruddin \& Haliza Hussein. (2011). Entrepreneurial Behaviour and Non-Cognitive Entreprebeurship Knowledge Among the Orang Asli Youths from the South Zone of Peninsular Malaysia. 10 ${ }^{\text {th }}$ WSEAS International Conference on Education And Educational Technology (EDU '11).

Norasmah Othman, Mohd Hasril Amiruddin \& Mazura Mansor. (2011). The Entrepreneurial Behavior Of Orang Asli Youths In South Peninsular Malaysia. International Journal Of Education And Information Technologies 1(5), 132-139.

Padil, S. (2012). Aplikasi Kemahiran Insaniah dalam Kurikulum Program Kejuruteraan di Politeknik. Tesis Sarjana. Universiti Tun Hussein Onn Malaysia.

Plsek, E. (1997). Creativity, Innovation, and Quality. Milwaukee, WI: ASQC Quality Press.

Ramachandra. (2013). The Big Jump into Entrepreneurship. Singapore: Horizon.

Reitan, B. (1997). Where Do We Learn That Entrepreneursship Feasible, Desirable And/Or Profitable. Norwegian University of Science \& Techonolgy, Faculty of Sosial Science \& Techonology Mangement Trondheim, Norway.

Sekaran, U. (2006). Metode Penelitian Bisnis. Jakarta: Salemba Empat.

Sidek, M. N. (2002). Reka Bentuk Penyelidikan: Falsafah, Teori, dan Praktis. Serdang: Universiti Putra Malaysia.

Stevenson, H. \& L. Bell. (2009). Introduction Universities in Transition: Themes in Higher Education Policy. The Future of Higher Education. New York: Continuum International Publishing Group, pp.1-16.

Yusof, A. A. (2000). Usahawan Dan Pengukuhan Jaringan Rakan Niaga. Sintok: Penerbit Universiti Utara Malaysia.

Yusof, H. (2008). Hala Tuju Pendidikan Teknik dan Vokasional. Kertas Dibentangkan di International Forum on Vocational-Technical Education, Hongzhou, China.

Yusof, Z. (2000). Sukarkah Komunikasi Anda: Seni Berhubung Dengan Orang Lain. Cheras: Utusan Publications \& Distributors Sdn Bhd.

Zaidatol Akmaliah \& Habibah Elias (1997). Keusahawanan dan Motivasi Diri. Selangor: Penerbitan Universiti Putra Malaysia. 